\title{
LIVEABLE CITY CHARACTERISTICS OR THE CONTINUOUS PROCESS OF URBAN TRANSFORMATION. URBAN EVOLUTION OR NEGLECT - A STUDY APPLIED ON BRAȘOV
}

\author{
Sansebeş Radu-Mihai \\ Architect, PhD graduate at 'Ion Mincu' University of Architecture and Urban \\ Planning, Bucharest (ROMANIA) \\ sansebesradumihai [at] yahoo.com
}

\begin{abstract}
We try to learn more from the examples of other cities or regions, but most often we do not know the history of our home city. Often, we try to implement a strategy or a modern principle unanimously accepted on a new site, regardless of the local history and the community needs.

Since the Middle Ages, the geographical position of the city has made Brașov a major centre for economic and cultural exchanges. However, Brașov's architectural heritage is unjustly ignored both by the large public and by the authorities.

The new challenges of the late twentieth century changed the role of industry in the society, both globally and locally. All these led to the change of its role in economic development. Industrial development and the need for labour mean that the city and reorganization of existing structures serve new needs. In the period under review new factories were built throughout the city, transforming the medieval town of Brașov into an industrial one.
\end{abstract}

Keywords: Urban planning, urban landscape, architecture, research, Brașov, study of urban planning, study of architecture, urban evolution, Brașov in the modern era, urban interventions, urban context

\section{STUDY PREMISES}

The concept of a 'liveable city' is more of an abstract term, with the emphasis on the sum of the characteristics that makes the city a proper place for living. It is a mixture of words, so newly introduced in the field of urban planning, that it does not have a solid theoretical ground of its own, but strongly relies on related concepts. A liveable city is more often the sum of the characteristics that makes the city desirable by the people. In most cultures this is the way that the term has been translated and interpreted. But, besides the main component, the will of the people, it relies also on elements and studies from inter and trans disciplinary subjects, architecture and urban planning being the last phase of the process, the interventions.

The main ingredient, the desirability of a city or an area is a difficult concept to quantify and often based on strong emotional components. On the other case, the other components that improve liveability, like the means of rehabilitation, are well defined concepts, measures and techniques, but most often they are hard to 
comprehend by the large population and hard to implement if we neglect the local context. The distance between theory and practice is becoming even larger when local governments are facing serious problems regarding both financial and human resources. All these criteria have to reach a perfect spot to maintain the equilibrium. The economic growth must be constant, health and education have to answer the social needs, and the city has to permanently evolve in a sustainable and rightful way so that the industry and the urban health have to remain in balance.

In the race for urban evolution, we try to learn more from the examples of other cities or regions, but most often we do not know the history of our home city. Often do we try to implement a strategy or a modern principle unanimously accepted on a new site, regardless of the local history and the community needs. In this way, we are introducing a constrained element that does not cope with the local culture or the local environment, this being solely based on the prestige source or synchronized measurements. We start from the wrong premise that history is the part we know of and that there is no need to refer to. Another wrong approach is the concept of some people that consider they are not living in history and they want a modern upgrade after established models or after social patterns and trends, whether they fit or not, with devastating local effect for the future and identity of our community.

This was the premise for a larger research study dedicated to my hometown Brașov. The studying of events that were related to urban planning and architecture is not enough to determine the accurate and complete of Brasov's picture of development in modern times. This study that I depicted is nothing but the main structure of my PhD study and analysis of my home town, called: "Brașov- A study of urban planning and architecture. Evolution of Brașov in modern times. Urban interventions in the period $1850-2015$ ", from the Ion Mincu University of Architecture and Urbanism in Bucharest (Romania). The well-known studies of my coordinating professor Alexandru Sandu influenced my research and determined an inter and trans disciplinary approach. One of the main reasons I have started this study was the lack of knowledge regarding urban growth and architectural interventions in the modern era. As popular as Brașov is, the city did not have a proper study of the evolution of the urban elements, but was only summarily portrayed. If the Middle Ages are well presented, even if the approach was more narrative than scientific, the modern times lack any study in the field of urban planning and architecture. So, the originality of this research came as an answer to be the first to fill the gaps, letting the doors open for other innovative studies to correct the elements that are in disorder.

I will try to resume the whole study to the main ideas, and see what elements made Brașov a liveable city, even with the uncorrected urban illnesses. The innovation is left for the professional activities and other studies with a more practical approach, a research of this kind being more often regarded as a theoretical coordinator. To better understand the urban interventions that contoured the city's image in the period between 1850-2015, we require a trans- and inter- disciplinary analysis. We can consider this example as a case study, with the methodology that can be easily implemented with other elements and characteristics that look alike.

The city's evolution depends on many factors and a plurality of information from several areas and fields. In terms of urban development, the study of Brasov's evolution involves both the analysis of changes in the streets structure and the emergence of important architectural buildings, but we must not neglect the 
historical context in which the political and economic transformations occurred. The city is not just the sum of its elements that compose it, but also includes all the relationships between the subsystem's components.

\begin{abstract}
"Urban structure analysis studies the relations existing at a given moment between the elements of the city as a system; comparatively, urban restructuring studies the possible further evolution of such relations, and especially the way they could relate with the necessities of the ongoing development of the city. Therefore, the urban restructuring process is actually an attempt of adaptation of the existing relations to new necessities; it is a process of implementation and development of the new relations within an urban existing context. The city as a whole appears as a kind of sedimentation, a final decantation of the material and spiritual existence results, understood by its people's life in its entire complexity and generational succession. This way, renewal is a necessary and steady process. In a city's existence, there may be periods of stagnation in this renewal process, but generally every beginning should be seen as another succession moment." [2]
\end{abstract}

Urban planning and territorial administration often treated this situation in summary, heritage been often given an intangible element. Without the context and the processes that gave value to the heritage, desirability is an abstract term that will remain just a concept for most people. The people that do not understand the value of these items will consider modernity as a more desirable component and will desire to dissociate themselves from the rest of the population that are still captive of memories and misinterpreted concepts.

Brașov's architectural heritage is unjustly ignored both by the large public and by the authorities. A natural step to make this heritage more accessible to population comes both as an urge to admire the monuments at their fair value and as a call to those who can fix the main problems of the city. But complex situations can only be resolved after a systematic review without claiming any definitive answers. Materials and study results rather recreate the conditions for possible future responses and approaches and, why not, compose the main data for a competition of ideas to remodel the whole city.

In such urban rehabilitation approach, the main objective should be the effort of summarising the processes that led to the modern urban changes and their impact on general urban image. The city restructuring process is made in the context of international events, the local component often being the surprise ingredient of the recipe.

\title{
2. DESIRABILITY, A PROCESS OF EVOLUTION
}

Since the Middle Ages, the geographical positioning of the city has made Brașov a major centre for economic and cultural exchanges. The strategic positioning at the crossroads of the main crossing routes between the Romanian main regions and at the shelter of the natural environment, the city developed initially due to the border trade and then through crafts and industries. The guilds have transformed Brașov in a strong craft centre and, by building walls, bastions, watchtowers, they have contributed to the ingenious system for defending the shops, churches and hospitals from within the city perimeter, all in the Europe medieval fashion way. 
In the modern era, in terms of urban planning, Brașov is growing exponentially. The great systematisation began with the mid nineteenth century, a period that is most common assimilated with the industrial revolution. Due to the frequent wars in the Romanian regions and the internal struggles for power, urban evolution is far lagging. We are witnessing a Middle Age that delayed the industrial revolution later brought to Brașov by visionaries, traders and entrepreneurs. Guilds go step by step with modern industrial plants and the city is witnessing a boom which creates the further urban development.

The main cell of medieval cities is the community that is organized around guilds of craftsmen and merchants. This cell undergoes significant changes, becoming a completely new organism. The new cell is not serving the economic and the defence function equally any more. The new cell contains complex subsystems cantered around economic or industrial units, where the company is only one component in the overall system. The medieval town system had a more natural process of reorganization and development, so the city had to adapt and include changes to the city's structure, architecture and urban landscape, that will mean also changes in strategy, management, economics, planning and finally changes to culture and social activities.

Almost all the urban interwar interventions were nothing but continuation of the interventions started in the previous period. The frequent political changes created an administrative vacuum and did not manage to impose an abiding rhythm. On the one hand things were placed on a good channel, the administration having established a precise route determined by an effective strategy for a longer period. The Law of the Unified Administration from 1925 has had a surprising effect. Planning and development could not be restrained, sound principles are those that will determine the rules that will influence further development of the city.

Brașov in the interwar period was not representative only by public buildings, but also by a developed road infrastructure, an effective urban planning, modern public lighting, a sanitation system, promenades, public services at a European level. With the emigration of German ethnics in reverse, part of these achievements will regress in the following period.

The systematization plan inherited from the Austro-Hungarian administration, is later abandoned, but parts of it can be found in the urban planning strategies that were later applied. Emphasis was placed mainly on industrial development, providing adequate housing to citizens involved in the industry is a secondary program necessary to ensure labour. Despite the millions of lives lost in both world wars, Romania was facing the highest demographic growth and thus housing shortages created severe overcrowding. The factory produces not only products but also generates profitable housing, schools, hospitals, in other words form a community around the industrial platform.

The financial crises of the interwar years, successive political disputes, social discrimination, "injustices ruling classes of the working classes"1 in January, austerity policies and general disappointment regarding the organization of early capitalism have caused major changes in the middle of the twentieth century. Traditional monarchies are replaced by new political systems through popular revolution. The

\footnotetext{
${ }^{1}$ This was a common saying used in communist leaders' speech, a theme taken up successively in political discourses against the capitalist system, taken without an ironic goal.
} 
world is divided into two camps, the selection criteria being adopted political and economic system: capitalism or socialism. Urban interventions and architecture are the mirror of society, they are directly influenced by the political and social changes, without being able to dissociate from each other. It is often used as a means of propagation of doctrines, architecture and urban planning become administrative tool programmers of the new political system.

In parallel with technological advances and industry momentum we are witnessing the gradual disappearance of the classical system of organization of cities. But modern period radically changes the rules of the war, becoming more mobile and with the ability to destroy heavy weapons away from any fortification. Thus, the walls are useless in terms of defence and recourse to demolish fortified belt on the north-east. Demolition city wall begins in 1857, when it gave up on the south side walls and fortifications to make way related Gate Street gate and allow unrestricted development directions of the city naturally. Followed later: Street Wear Black (1873), Gate Horse Fair (1874), Bastion Goldsmith (1886), Bastion harness (1887) and other urban interventions has led to traffic flow between centre and periphery.

Expanding urban texture of Brașov was precise and predictable product lines. Due to the naturally restricted transformation from a medieval town to a modern city it has been clearly defined to the north-east, towards Brasov's Old Town and Blumana neighbourhood. The nature and the city offered Brasov's Schei neighbourhood protection and development of the city to the west meant a bond between the two communities on either side of the walls. Upgrading old fortress was produced following the model Austrian model applied in Vienna ${ }^{2}$ arguments for demolition being given by the high costs for maintenance and preservation futility walls in the context of a new defence system based on mobile troops and heavy artillery. Quitting fortification walls involved a better access thoroughfares and development of the centre and surrounding neighbourhoods. Also, due to the nature, Brașov has the option not to invest in upgrading medieval fortifications and their adaptation to the modern system, the model met in seventeenth and eighteenth centuries. Medieval walls had no chance against artillery, but nature gives the necessary protection and angles that favour defence.

In medieval times the old ditches adjacent walls had defensive role and the role of supplying the city with fresh fish population in peacetime. Becoming useless against modern techniques of attack and being somehow neglected, they were drained, with ponds and swamps around the city. The land thus recovered has allowed a rapid urban development outside the walls, the place was taken by high public and administrative buildings, schools, barracks and sumptuous villas, arranged parks and promenades.

Industrialization brought more people from rural areas to cities. The process of nationalization and transformation of villages in agricultural production cooperatives hastened the migration of the population. But the main problem was the low number of available housing units. Immediately after the war the focus was placed on the reconstruction and development of the industry, both to ensure an increase in future economic growth, and strategic considerations. Only this should be supported by

\footnotetext{
${ }^{2}$ Vienna's Ring (in German Ringstrasse) is a circular road surrounding the old town (Innere Stadt Wien district) and is one of its main attractions. The architecture is typical eclecticism called Ringstrassenstil (ring road style) and was carried out between the years 1860-1890.
} 
population growth. Industry acute need for labour led to encouraging growth population by absurd measures against abortions, facilities for young families and an extensive program of new housing construction.

Thus came the first strict limits on housing ascribed to each person. It gave up everything meaning comfort, functional apartments schemes including minimum. Such separate dining room (the room) disappeared from the standard configuration. In general, each person entitled to about 9 or 10 square meters and often, more people must share the same room. Two or more generations of the same family will often share an apartment originally built for one family. At the end of the1980's objective of the scheme was to provide a heating for every citizen, an objective that was never achieved before.

During the Cold War, urban planning in Soviet Bloc countries was dictated by ideological and political reasons. Party leadership is often guided by principles addressing social protection and welfare of society, but individual interests of the citizen were ignored in favour of a general benefit to society. In your word leaders were those who took the best decision for society and the population had to comply. Often the main arguments of "reform" were the ideological principles of social and economic criteria. These principles were reflected in urban design and architecture in all communist countries, most citing a centrally controlled development and lightweight construction methods. Communist planning led to identical models (with some local variations) in the entire Soviet Union.

In the first socialist decade, most resources were directed towards industrial development and reconstruction of cities affected by the Second World War. In many cases, the reconstruction was carried out spontaneously, without a detailed urban planning. Because rebuilding had to begin immediately it was not enough time to set up a detailed plan of urban organization. This is why many interventions were based on old plans of development before the war. The system also pursued a policy hostile to intellectuals and qualified personnel to carry out urban plans was not available. In the process of socialist industrialization, large platforms and industrial plants were built not only around existing cities, but also in the vicinity of rural communities, creating new urban communities around dedicated workers.

Brașov suffered significant damages during the Second World War, but being an important industrial and economic pole, the reconstruction was absolutely necessary. After the nationalisation process, almost all the financial resources and land ownership were under the control of the government. The reconstruction, the development and the new investments had to be financed by the state. According to communist ideology, building the socialist industry was the first step in building a new society. The ideology was closely related to the Soviet Union's interest in recovering the post war duty. Even though, in the name of the debt, Romania was stripped of the main resources required to support the reconstruction of the Soviet bloc, and had been denied the right of economic and social reconstruction, the principle of forced industrialisation has helped to maintain a steady pace of development and an upward trend.

By comparing socialist urban planning to Western urban development, we can point that the main focus was not just a (re)-organisation of functional areas, but often included the complete redesign of whole city areas. Speed was of the essence in all socialist societies, development plans exceedances being often reported. Throughout all the Soviet bloc, the Industrial Revolution took place very late, so 
development was seen as a matter of urgency of catching up to Western cultures. The demographic boom and the rapid pace of industrialization could not be sustained only through mass construction of residential buildings. The development of new neighbourhoods was a necessary effort of urban planning to expand the capacity of the cities to accommodate the growing number of people. Even if this resorted to rapid building, using precast concrete and putting aside the elements of comfort and the finishes, the housing crisis still caused overcrowding.

The architecture of the mid twentieth century is often ignored, and this phenomenon happens not just locally. The desire to catch up the west and the need to demonstrate the bad things that take place in the capitalist system led to a lot of urban experiments. The development of urban planning and architecture often tracks modernist ideas, often translated into socialist political language. An example might be borrowing the ideas of Le Corbusier in Paris modernisation package for the systematic methods of socialist cities - the micro district. Including systematisation term is translated from Western urban planning. The entire construction system is standardised and mass-produced with a very clear objective: to reduce costs.

The political changes that took place at the end of the twentieth century completely neglected the urban processes and from this, urban planning suffered from a long list of constraints. In the desire for a radical change, in the name of the evolution, the people entered a forced process of amnesia. Urban planning, as well as other main areas of interest were liberalized and the city lost the chance of following a coherent development plan. We are thus witnessing a mutation in which the public urban space was assaulted by 'visionary' people (the first small companies) occupying the space with elements of the 'new trade' - the kiosks. Authorities were unable to manage the situation, but were satisfied to collect taxes, leaving the improper shopping to prosper.

\section{ANALYSIS OF THE CONTEMPORARY SYSTEM}

The political and administrative inconsistency caused some urban elements to behave like cancer. Architecture is being assaulted by a bad "traditional" style. Constructions and ancillary constructions appear without government's control of the phenomenon. Many of the materials are purchased from the large industrial platforms, so we can see the same metal profiles used on all balcony enclosures and all extensions or kiosks that concurred the urban landscape. In an attempt to mitigate the harmful effects of these harmful interventions, the local authorities opened the 'balcony' season. In this context, the urban general image is directly affected by the non-unitary closure of balconies, the carpentry replacement and the partial thermal enveloping, the facade being the witness of the decisions that took place on residential associations meetings.

The economic and political crises, followed by a fierce long lasting recession, emphasized the problem of the use of the space that resulted from the disappearance of some economic functions. The residual space is perhaps what architect Rem Koolhaas called 'junk space'. After the dissolution or bankruptcy of some large industrial sites, the land has become an improperly used space for the city. The productive cells are replaced by some apartment buildings and retail stores. The trade is the modern binder and the and urban catalyst of change. 
In this urban context, spatial planning becomes a major problem for Brașov because of the economic, political and sometimes social implications. In Brasov, the problem of the rational use of land as a non-reversible wealth was harder envisioned in the working practices, probably being increased by the lack of political will and the existence of some ideologies inherited from the communist era. During this period, the main urban problems were amplified, mainly due to insufficient allocation of resources for solving these problems. Time and finance seem to be the main reasons given. By joining the European Union, entering the common market and reducing the government intervention aimed at frequent political disputes, favouring the economic recovery. Without a functional arbitration system, the market was forced to self-regulate and Romanian economy continued to flourish under the impact of EU community trade market.

Urban planning is being liberalized and is not the direct responsibility of governments or administrations anymore. Public administration took part of the development initiative, but to a very limited extent, urban planning will be dependent on the will of the gainer. The private sector is too young and intervention in urban development is too small to be noticed. In the best case, we can say that local interventions of some companies have determined economic development and have increased urban development. These constructions have led to new interventions in the area and the city has expanded to these new poles of interest.

Trade is modernised, urban space is released, the urban system is ordered, but the process is slow and often is undesirable. The freed-up space that resulted after the removal of stalls is rearranged by the city administration as public space and in this way the space becomes again interesting for society, while trade (re)becomes civilized. Unfortunately, cultural functions are gradually removed due to low popular interest and poor funding. An immediate effect is the disappearance of cinemas and bookstores.

\section{CONCLUSIONS AND FURTHER MEASURES}

The first step in implementing an intervention is to know the given situation in detail. By synthesising the analysis, we get a set of principles that will determine future actions, just as an intervention in a building site is necessary to consider the context or the specific site. Context is known more formally as genius $10 \mathrm{c}^{3}$ or the genetic fingerprint of a place, our experience being the one that is dictating to us how urban intervention can take place.

A detailed study of how the city's changed role in different periods of history helps us better analyse the context in which the city evolved under the influence of political pressure. Social changes and economic context determines mutations of the classic urban system. Brașov's 'Downtown' develops in a uniform way, with a focus on city development in the Middle Ages, but urban momentum is generated by the industrial revolution and the rampant industrialization that was imposed. Renaissance and

\footnotetext{
${ }^{3}$ In classical Roman culture, genius loci represented the protective spirit of a place. This term has been loan from the Latin and it means: genius representing spiritual and loci, singular genitive of locus, representing the place, that instead of the term representing the special atmosphere composed of a specific place. Alexander Pope turned genius loci an important principle in the product and landscape design. The term was inherited in modern times also in other areas, underpinning the phenomenological research.
} 
Baroque are much delayed and we can say that Brașov (like many other cities in Romania) jumped directly to modern times. The changes are fast, in this way the craftsmen's city becomes an industrial metropolis. Urban planning is identified with town-planning and must adapt to the needs of the modern society and new political doctrines. Road structure formation, expansion of built-up, urban impacts on the social aspect and politics are complex elements and distinctively influence the development of Brasov. The spatial distribution of functions, and specialized migration of labour near the workplace and semi-autonomous decisions outlined the overall image of the city. The economic development was the engine of the urban development ${ }^{4}$ and local economic crises, national or global social even doctrinal crises that have started. The imposing city limits caused intensification of the built tissue and the optimizing of the existing space resources. Brașov has no shortage of free land for construction, so the demolition of old tissue was not necessary, but was rather used the reorganization of existing texture and the intensification of residential functions. It stimulated economic regional growth by providing new production activities and development of existing industry. As one of the main industrial poles of the country, with a good potential for recovery, the state nationalized invests in production to maximize profits.

The new challenges of the late twentieth century changed the role of industry in the development of society, both globally and locally. All these led to the change of its role in economic development. Industrial development and the need for labour mean that the city and reorganization of existing structures must serve new needs. In the period under review, new factories were built throughout the city, transforming the medieval town of Brașov into an industrial city.

Urban development is also a sign that the Great Union acted as a binder economy and as a factor stimulating the development of the country, for both the lessurbanized Wallachia and Moldova, as well as the provinces with a more developed urban civilization that belonged to the defunct Austro-Hungarian Empire, joined by Great Union to the mother country. Brașov is thus witness to an industrial development as most of the Old Romanian Kingdom never had and never will have, at least until the eve of World War II. At the same time, we cannot talk about an urban civilization with the Romanian element being dominant because of centuries of discrimination on ethnic and religious reasons. Thus, the interwar period is a transition phase for the Romanian element.

By any means filling in the urban picture is important, even if the research method is borrowed from different areas of expertise. Depending on the situation, alternative methods can provide important data for the research study. Another important means of information, but neglected by academic researchers, is the gathering of some stories of the past events through direct contact with designers of that time that are retired and ignored in the contemporary period. Informal dialogue is the first step of documentation. The reviews are then verified by cross-checking and double the number of sources, thus reducing the danger of shaping an inaccurate image. All these emerge into a puzzle that contains missing parts, but can, however, be subject to further detailed research.

\footnotetext{
${ }^{4}$ Both to increase the returning of war debt to the Soviet Union by SovRom companies and the economic development of the society of The Socialist Republic of Romania.
} 
Even though the main subject of my research was to portray the urban picture in the historical-political and social-economical context, I will try to point out some possible actions that can help the city in becoming more or remaining still livable. There are plenty of examples and analysis on walkability ${ }^{5}$ and how the city can be improved by introducing bike lanes.

"Walkability is a measure of how friendly an area is to walking. It takes into account the quality of pedestrian facilities, roadway conditions, land use patterns, community support, security and comfort for walking" [6].

This may be the topic of another study and is often regarded not being the subject of a Ph.D. research but most likely the product of a more practical study. We can point out the example of some cities in implementing the bike lanes by copying the model of Amsterdam or Copenhagen. The set of rules made by engineers that administer and design the whole system, with years of experience, can be exported and are also known as 'Copenhagenise' [7]. In this way, they can advise other city municipalities from around the world regarding, street infrastructure, urban strategies and bicycle planning, but without the proper analysis this will not turn to the regenerating method that is intended to be. These new urban planning rules must be applied only after a strict analysis and synthesis, with proper guidance from the experts in the field and avoiding by any means the bad behaviour of copy-pasting the modern trends from the Western cultures.

All these elements are necessary for a better understanding of the current urban landscape. The components and the relationship between the urban subsystems is more than the sum of its components. But the findings are related individually to each observer and his or her ability to synthesise the information.

\footnotetext{
${ }^{5}$ Walkability is a measure of how friendly an area is to walking. Walkability has health, environmental, and economic benefits. Factors influencing walkability include the presence or absence and quality of footpaths, sidewalks or other pedestrian rights-of-way, traffic and road conditions, land use patterns, building accessibility, and safety, among others. Walkability is an important concept in sustainable urban design.
} 


\section{REFERENCES}

[1] Sansebeș R. M. (2017), Brașov - A Study of Urban Planning and Architecture. Evolution of Brașov in Modern Times. Urban Interventions in the Period 1850-2015, $\mathrm{PhD}$ thesis, graduated at the Ion Mincu University of Architecture and Urbanism in Bucharest (Romania), manuscript.

[2] Sandu A. (2007), The Kernel that Makes It Grow, Arhitext's architecture magazine collection of book "Archive of Ideas", chapter "For a Complex, Scientific Comprehension of the Urban Restructuring", Arhitext Foundation Editor, Bucharest, pp. 147-185.

[3] Băldescu I. (2012), Medieval Transylvania - Surveying and Legal Norms of the Cities Sibiu, Bistrița, Brașov, Cluj, Simetria Publisher, Bucharest.

[4] Cioroianu A. (2005), On the Shoulders of Marx. An Introduction to the History of Romanian Communism, Curtea Veche Publisher, Bucharest.

[5] Curinschi-Vorona G. (1977), World History of the Illustrated Architecture, Technical Publishing House, Bucharest.

[6] Jenei D., Zamfir A.M., Hilohi G., Nussbächer G. (2003), Brașov: A Brief Illustrated History of the Urban Development", Reform V S.R.L. Publisher, Brașov.

[7] Cappellanti S., Cefalo A., Grignaffini S. (2008) "Visualizing sustainability in Urban Conditions", WIT Transactions on Ecology and the Environment, 1, pp. 253-262.

[8] Colville-Andersen M. (2017), "Bicycle Urbanism by Design", Conference at Concordia University's Department of Geography, Planning and Environment and Concordia University Research Chair in Integrated Design, Ecology And Sustainability for the Built Environment, Montreal, Canada - documentation available on www.copenhagenize.com and presented also during TEDx Zürich (2012) conference by Mikael Colville-Andersen on October 25, Swiss National TV (SRF), Zürich, Switzerland. 